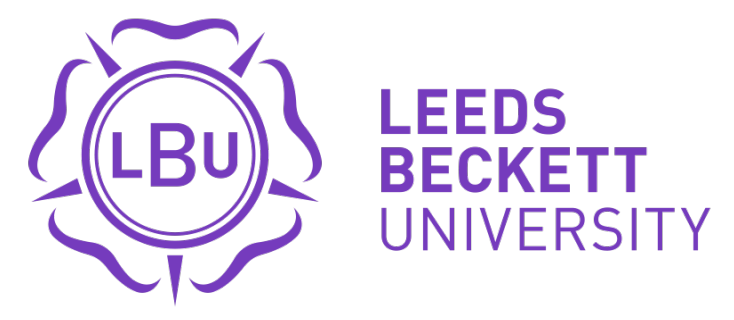

Citation:

Osuoha, J and Samy, M and Osuoha, O (2015) The Impact of Corporate Governance on Derivatives Usage-Empirical Evidence from African Non-Financial Firms. British Journal of Economics, Management \& Trade, 8 (1). 19 - 31. ISSN 2278-098X DOI: https://doi.org/10.9734/BJEMT/2015/15580

Link to Leeds Beckett Repository record:

https://eprints.leedsbeckett.ac.uk/id/eprint/2138/

Document Version:

Article (Published Version)

Creative Commons: Attribution 4.0

The aim of the Leeds Beckett Repository is to provide open access to our research, as required by funder policies and permitted by publishers and copyright law.

The Leeds Beckett repository holds a wide range of publications, each of which has been checked for copyright and the relevant embargo period has been applied by the Research Services team.

We operate on a standard take-down policy. If you are the author or publisher of an output and you would like it removed from the repository, please contact us and we will investigate on a case-by-case basis.

Each thesis in the repository has been cleared where necessary by the author for third party copyright. If you would like a thesis to be removed from the repository or believe there is an issue with copyright, please contact us on openaccess@leedsbeckett.ac.uk and we will investigate on a case-by-case basis. 


British Journal of Economics, Management \& Trade
8(1): 19-31, 2015, Article no.BJEMT.2015.096
ISSN: 2278-098X

\title{
The Impact of Corporate Governance on Derivatives Usage-Empirical Evidence from African Non-financial Firms
}

\author{
John Ifeanyichukwu Osuoha ${ }^{1 *}$, Samy Martin ${ }^{1}$ \\ and Ebun-Oluwa Oluwatoyin Osuoha ${ }^{2}$ \\ ${ }^{1}$ Department of Accounting and Finance, Leeds Business School, Leeds Beckett University, Leeds, \\ United Kingdom. \\ ${ }^{2}$ Department of Finance, University of Lagos, Nigeria.
}

Authors' contributions

This work was carried out in collaboration between all authors. All authors read and approved the final manuscript.

Article Information

DOI: $10.9734 / B J E M T / 2015 / 15580$ Editor(s):

(1) LI, Hui, School of Economics and Management, Zhejiang Normal University, China. (2) Stefano Bresciani, Department of Management, University of Turin, Italy. Reviewers:

(1) Prachi Singh, Department of Commerce and Management, Pandit Ravishankar University, Raipur, India.

(2) Anonymous, China.

(3) Anonymous, Nigeria.

(4) Anonymous, Indonesia.

(4) Complete Peer review History: http://www.sciencedomain.org/review-history.php?iid=1061\&id=20\&aid=9215

Original Research Article

Received $5^{\text {th }}$ December 2014

Accepted $31^{\text {st }}$ January 2015

Published 11 ${ }^{\text {th }}$ May 2015

\section{ABSTRACT}

The study investigates the impact of corporate governance on derivatives usage in African nonfinancial firms. Using a sample of 760 African non-financial firms from 17 African countries, the study shows that derivatives usage among African non-financial firm is very low. The study finds that the main reasons why most African firms do not use Derivatives are lack of knowledge about derivatives, absence of organized derivatives market and absence of derivatives experts. The results also show that Board composition is the strongest measure of corporate governance impacting derivatives usage. Derivatives usage increases with increase in the number of executive directors but has an inverse relationship with the board size. Derivatives user firms have strong corporate governance in place to mitigate the risk of derivatives misuse that could hurt the firms. 
Keywords: Derivatives; Financial Engineering; Corporate Governance; Risk Management; Nonfinancial firms; Africa.

\section{INTRODUCTION}

Derivatives are financial instruments that derive their value from the value of other instruments. Just like apple juice is derived from apple fruit and orange juice from orange fruit, derivatives are derived from basic financial instruments and variables such as shares, bonds, treasury bills, interest rates, exchange rates etc. Derivatives can also be derived from commodities such as agricultural produce, precious metals, energy/oil and gas, power, weather condition, emission to mention but a few. Derivatives are basically used to manage risks associated with the basic instrument on which they have been derived. They can also be used for speculation and arbitrage. The key roles of derivatives in an economy include hedging, price discovery, market completeness, market efficiency to mention but a few.

A derivative product can be either exchange traded where a contract is bought or sold on an organized derivative exchange or it can be over the counter (OTC) [1]. Exchange traded products have contract specification and they are standardized. Examples are futures contract and listed options. Whereas futures can only be traded on an exchange, options can be traded as an OTC or exchange traded. Forward and swaps are basically OTC derivatives. Fig. 1 illustrates this.

Good corporate governance is essential to the working of derivatives market [2,3]. Underscoring the need for corporate governance on firms that use derivatives, [4] observes that derivatives can be likened to electricity which can be beneficial and at the same time can be harmful if not properly used. In that study he also relates derivatives to a two edged sword that must be handled very carefully. Hence there must be strong oversight over the use of derivatives by Management in firms and Institution where derivatives are used. Many cases of derivatives mishaps results from the wrong application of derivatives instruments. Some of the misapplication results from lack of internal controls and sound corporate governance $[5,6]$. Instituting sound internal controls and corporate governance practices in the firms that use derivatives will help to moderate the risk of misuse of derivatives. According to [7], corporate governance can provide mechanism to effectively monitor the use of derivatives.

In their explanation of the concept of corporate Governance, [8] observe that "Corporate

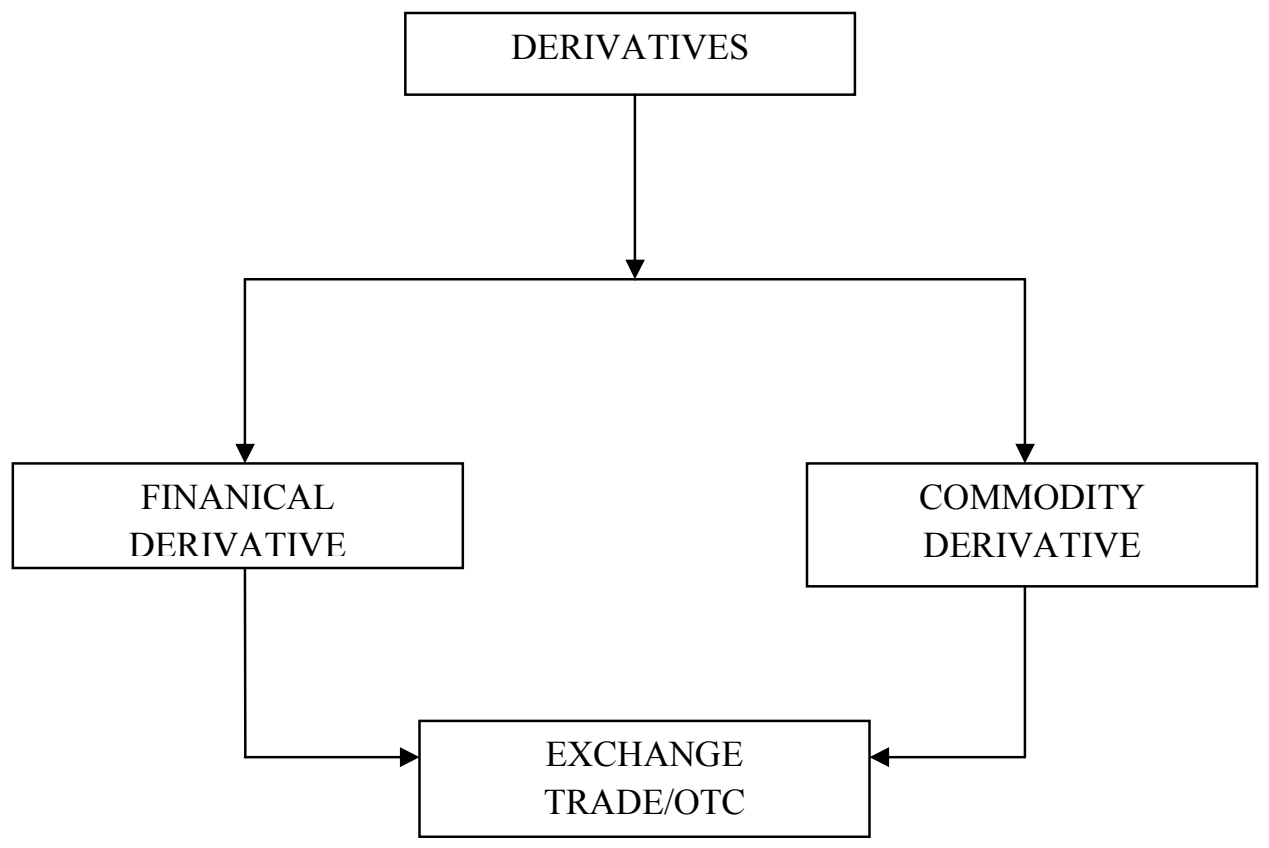

Fig. 1. Derivatives grouping

Source: Author 
governance deals with the ways in which suppliers of finance to corporations assure themselves of getting a return on their investment. Corporate governance is the entails an entire network of formal and informal relations involving both the private and public sectors of the economy. It is also concerned with the appropriate board structures, processes and systems that will drive the enterprise towards the achievement of its set goals. To [9] in its broadest sense, corporate governance is concerned with holding the balance between economic and social goals and between individual and communal goals. The governance framework is there to encourage the efficient use of resources and equally to require accountability for the stewardship of those resources. The aim is to align as nearly as possible the interest of individuals, of corporations, and of society.

According to [10] "Corporate governance involves a set of relationship between a company's management, its board, its shareholders and other stakeholders". On his part, [11], describes Corporate governance as "the process carried out by the board of directors, and its related committees, on behalf of and for the benefits of the company's stakeholders, to provide direction, authority, and oversights to management".

\section{LITERATURE REVIEW}

The firm's ownership structure may have an effect on the desirability of hedging and effectively monitoring the use of derivatives [5]. In another study of the effects of the use of corporate derivatives on the foreign exchange rate exposure with respect to ownership of 62 Australian Multinational Corporation, the study investigated the impact of the use of derivatives on the foreign exchange rate exposure, [12] find that the percentage of shares held by blockholders and institutions are significantly associated to foreign exchange exposure while the percentage of shares held by directors are not significantly associated to exposure. The study also finds that firm size has no significant effect on exposure. This position has been countered by [13] who studied what motivate banks to use derivatives in Taiwan and find that the propensity to use derivatives is positively related to bank size, currency exposure and issuance of preferred stocks, while negatively related to leverages and diversification of long term liabilities. A bank's decision to use derivatives is related to the proportion of outside directors, which we have described in this study as the Board Composition (BC) (Please see Fig. 2). Less informed outsider board members may have concerns about derivatives use due to their impact on the bank's leverage and risk taking. According [14], a well knowledgeable Board with good understanding of risk management can help improve derivatives use and enhance firm performance. In a survey of the understanding and monitoring of derivatives in a small sample of quoted firms, designed to find out if the non-executive directors have the wherewithal to oversee a firm's derivatives policy, [15] find that two-thirds confessed inadequate knowledge of derivatives while threequarters favour the use of derivatives in appropriate circumstances. [16], find that the foreign currency hedging premium is statistically significant and economically large only for firms that have strong internal and external corporate governance. Corporate governance can provide mechanism to effectively monitor the use of derivatives [7]. Corporate governance is necessary for participants in the financial market to trust the place, product, processes, price and promotion offered by the market and its players. Since the derivatives market is considered risky, its modus oparandi must be characterized by transparency and good governance [17]. As stated earlier, the real issue with Global Financial Crises (GFC) seems to be corporate governance and regulatory problems. The report of [18] released on January $27^{\text {th }} 2011$, identified the causes of the GFC to include: widespread failure in financial regulation; dramatic breakdowns in corporate governance including too many financial firms acting recklessly and taking on too much risk; explosive mix of excessive borrowing and risk by households and Wall Street that put the financial system on a Collision course with crises; key policy makers ill prepared for the crises, lacking a full understanding of the financial system they oversaw; and system breaches in accountability and ethics at all levels [18]. All these issues in one way or the other relate to corporate governance and regulatory failures.

According to [19], outside directors have more incentives to make decisions that benefit shareholders than do inside directors. There are some findings of favorable reaction by the equity markets to decision made by boards with greater proportion of outside directors. Management, though skilled in running a firm in a particular industry, lacks the broader knowledge supplied by the outside directors. In a study 'Board 
Composition and Corporate use of Interest Rate Derivatives', [20] established a positive relation between the relative influence of outside directors and the quantity of derivatives used, indicating that outside directors take an active role in derivatives usage and that firms employ hedging in the shareholders best interest. The study also shows a significant and positive relation between the quantity of interest rate derivatives used by firms and the proportion of outside directors on the firm's board. The size of the board, described as Board Size in our study (BS) has also been found not to be significantly related to the quantity of corporate derivatives use [20]. There is no evidence to suggest that managers benefit from corporate interest rate derivatives use at shareholders expense. But [21], argues that independent directors have not demonstrated any special skill to monitor or manage risk. According to [22], most board members of AIG were independent apart from 2 of the 12-16 board members of the parent company. Enron had 11 independent directors out of the 14 board members. Also Citigroup had majority of its board members as independent and yet they accumulated toxic assets. These independent board members could not discover nor manage the excessive risk taking of their firms. [23], empirically show that both hedge funds (HF) and private equity fund (PE) investments is driven by corporate governance improvements but seem to address different types of agency conflicts. Hedge Funds engage in variety of assets classes, such as equity and debts, commodities, options, futures and foreign exchange of which activities related to publicly listed firms represent only a few among numerous strategies. Private Equities invest in equity investments. The losses incurred through the use of derivatives by Procter and Gamble, Gibson Greetings and other firms and the far greater oversight of derivatives [20]. [24] also reechoes this call for greater oversight over derivative policies adopted by firms. But a firm's risk-management policies, especially those pertaining to the use of derivatives should be strongly influenced by the policies of the Board of Directors [20].

Earlier, [25] found that bonus payment provide managers an incentive to choose nonlinear derivatives. Smith and Watts (1992) reported a positive relationship between option compensation and investments opportunity. [26] believes that CEO with longer tenure develops skills unique to a specific firm and that makes them more risk averse. [27] shows that CEO's age serves as a proxy for risk aversion since their shorter retirement horizons provide the incentive to reduce the variance of their investments portfolios, which usually consists heavily of their own corporations' stocks. CEOs who receive more stock options have incentives to use nonlinear derivatives since firms generally award options at the money. Board of Directors of Corporation should carefully consider their firm's optimal derivatives strategies when making compensation decisions (Huang et al. 2007). A thorough review of what went wrong during the Global Financial Crises reveals the need to reduce systematic risk or improve the efficiency of the derivatives markets. Also there is need for centralized clearing, improved price transparency, improved position transparency, migration of Over the Counter (OTC) derivatives trading to organized exchanges, fixing speculative position limits and improved corporate governance. But [22], believes that the global financial crisis was inflated by a combination of government policy, unscrupulous lending practices and financial engineering. According to [22], because the risks of the housing market had been repackaged, split into smaller pieces and widely distributed, the effects soon spread throughout the entire economy. To him, the financial technology that enabled the risk to spread included principally securitization but also included derivatives. It is argued that financial engineering techniques allow a firm to change rapidly its risk exposure through the use of derivatives, which makes its risk profile much less transparent and much more dynamic and challenging. Most firms appear to have inadequate internal accounting and control systems to track derivatives transactions on a timely basis.

\section{METHODOLOGY}

We use 1998 Wharton Study Survey methodology to study a sample of 760 nonfinancial firms selected from 17 African countries. The 1998 survey is an extension of two previous surveys done in 1994 and 1995. The first survey was conducted in 1994 on US non-financial firms and published in Financial Management by [28]. It was later reviewed in 1996 with a broader range of questions about valuation and risk management and with more specific questions about the use of derivatives. One primary objective of the survey is the development of a database on risk management practices suitable for academic research. The model has since been adopted in many studies in both developed 
and emerging market economies. For developed economies, the survey has been used in New Zealand [29], Japan [30], Sweden (1999), Australia [31] to mention but a few. In emerging market economies, the survey has been used in Latin America [32] in which it has been shown that there is a significant use of derivatives in financial firms in Argentina, Brazil, Chile and Mexico. Similar survey was used in a study in Peru [33], on 'Derivatives Usage by NonFinancial Firms in Emerging markets: The Peruvian Case'. In Nigeria, [34] used the Wharton Study Survey in their study on 'Foreign Exchange Derivatives in Emerging Economies: Evidence from Nigeria Financial Service Industry'. One reason we chose to use the survey and Questionnaire method of data collection is that most African firms do not disclose the notional value of their derivatives use in their annual reports and accounts, making their derivatives data unavailable. This is not surprising because according to [28], firms are not willing to disclose their level of derivatives usage even in advanced economies with strict accounting rules. The second reason is that for virtually all African country (except South Africa), there is no organized derivatives exchange where data can be obtained on firms derivatives use. Thirdly it is only through a questionnaire that we can easily capture the motives behind the firms use or non-usage of derivatives, the kind of exposure they are managing with derivatives, level of derivatives knowledge and training among top management and board, corporate governance practices of the firms and Board monitoring of derivatives usage. Most information required for our analysis can only easily be obtained from a survey questionnaire. Even in advanced countries (with easy access to data) where this kind of study has been done, the researchers chose to use the survey methodology as it gives relevant data required for analysis [29,30,31]. The Wharton School Survey model has also been applied in crosscountry studies having been used by, to study the whole of Latin American Banks and by [35] in a single study of small and large economies. [36] applied the same methodology in studying Derivatives usage in both the United States and Germany.

Considering the size and heterogeneity of the evaluated segments, a confidence band of $95 \%$ was used to determine the sampling dimension and in obtaining a valid size of 265 observations to represent the population and the selection done by random sampling. Some filter questions were included such as questions on perception on regulations and derivatives knowledge. The liker scale was also utilized with metric and dichotomous questions to analyze the variables as was done in the study by [33]. The study estimates internal consistency using Cronbach's Alpha coefficient which has a value of 0.779 in a pilot survey. The administration of the questionnaires was done from July to October, 2014. The Cronbach Alpha's coefficient after receiving responses was 0.783 ; the final sampling error was calculated as $6.02 \%$ which is considered acceptable for the study. Logistic regression analysis was employed in the analysis of collected data. Preliminary survey results were analyzed using survey tabulation. This allowed us to compare and contrast the tendencies of the different variables.

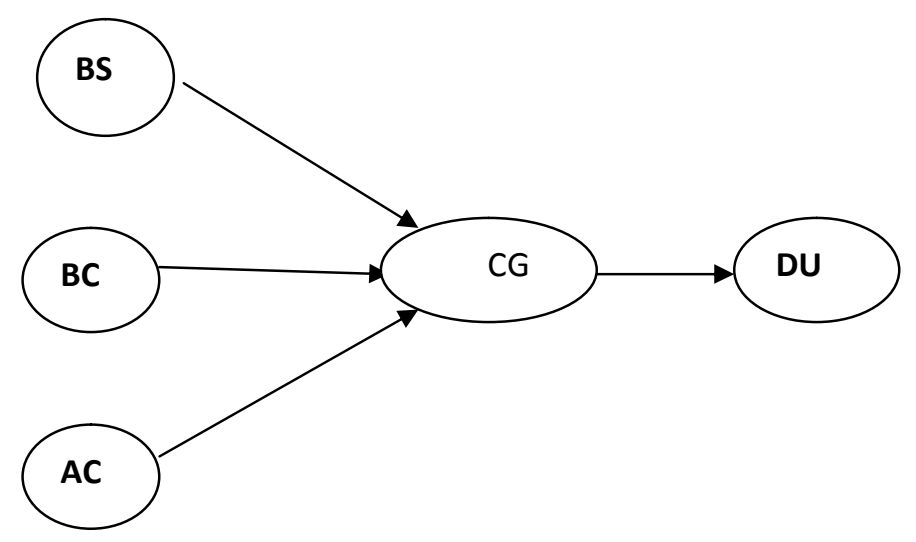

Fig. 2. Corporate governance and derivatives usage

BS: Board Size; BC: Board Composition (Captured by No. of Executive Directors, No of Non-Executive Directors and No. of Independent Directors); AC: Audit Committee (Also including Risk Management Committee and Documented Policy on Risk Management); CG: Corporate Governance; DU: Derivatives Usage; Source: Author 


\section{RESULTS AND ANALYSIS}

Responses were received from 267 firms out of the 760 making up the sample. This yields a response rate of $35 \%$. Two of the responses were considered invalid as they were not properly completed. This leaves us with only 265 valid responses representing an effective response rate of $34.87 \%$. The 265 valid responses were utilized in the analysis. The result on the use of derivatives in African firms as displayed in Table 1 above gave the overall percentage of firms that use derivatives as $38.5 \%$.

Comparing the level of derivative usage last year with this year revealed that 68 out of the 102 respondents (67\%) whose companies use derivatives reported that usage increased; 10 out of the $102(10 \%)$ reported decrease in usage while 18 out of the 102 reported that usage remained constant. 6 did not respond to the item. Please refer to Fig. 3. This is also consistent with Bodnar et al. [37] where derivatives usage increased in $42 \%$ of the firms and decreased in $13 \%$ of the firms. The increase in usage suggests that firms are finding derivatives usage beneficial and performance-enhancing for them to choose to increase its usage.

\section{Table 1. Composition of respondents according to derivative usage}

\begin{tabular}{lll}
\hline Company & Frequency & $\begin{array}{l}\text { Percentage } \\
\mathbf{( \% )}\end{array}$ \\
\hline $\begin{array}{l}\text { Companies that } \\
\text { use derivative }\end{array}$ & 102 & 38.5 \\
$\begin{array}{l}\text { Companies that do } \\
\text { not use derivatives }\end{array}$ & 163 & 61.5 \\
\begin{tabular}{l} 
TOTAL \\
\hline
\end{tabular} & 265 & 100.00 \\
\hline
\end{tabular}

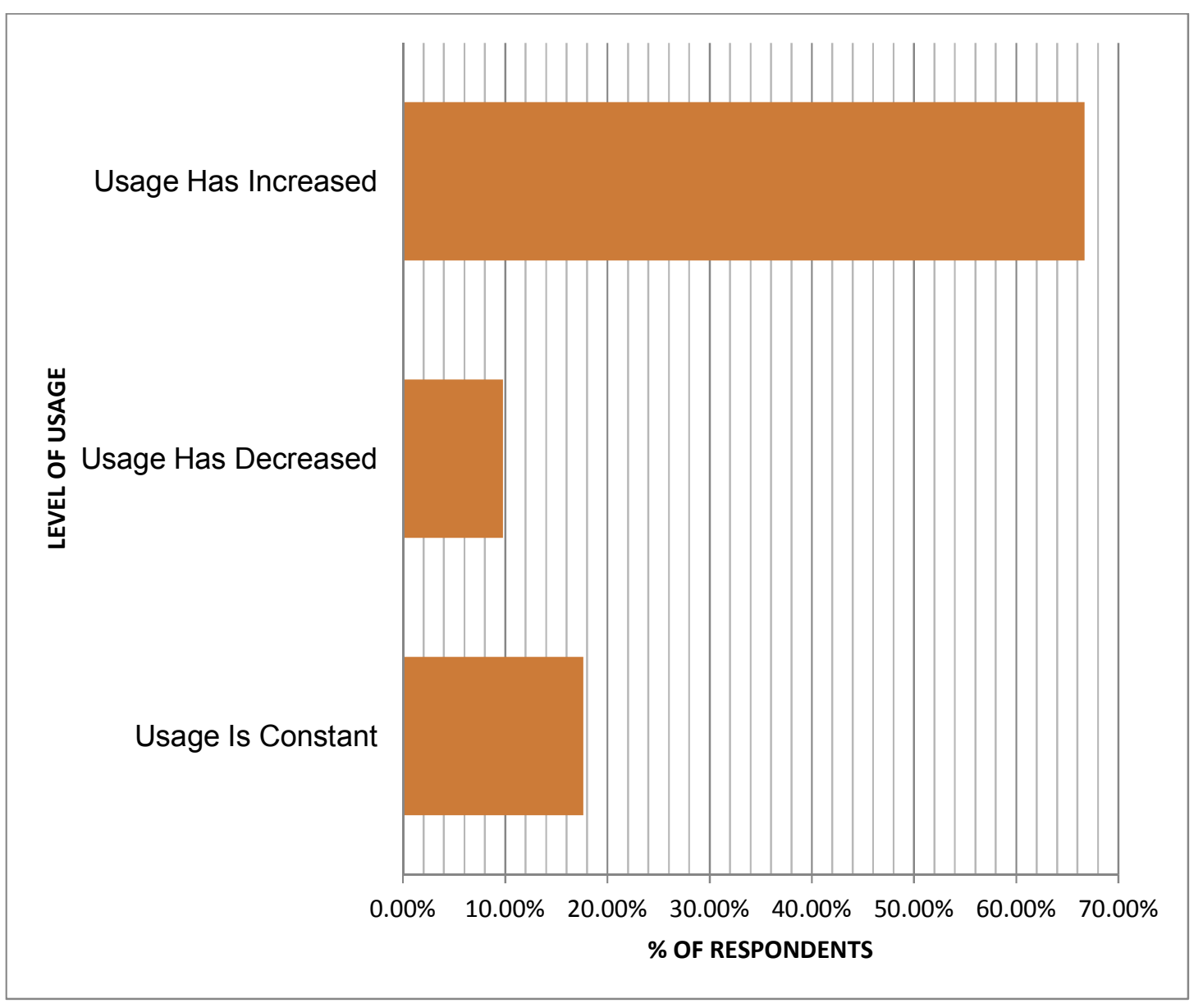

Fig. 3. Derivatives usage compared to last year 
On the type of derivative usually employed by firms, 49 out of the 102 claimed that they employed forward contracts, 10 future contracts, 20 option contracts, 15 swaps, 8 reported other types of derivatives. This is shown graphically in Fig. 4. Forwards and Swaps are purely OTC contracts. Options are mostly OTC but can also be exchange traded. The above results suggest that most firms in African use OTC derivatives as against exchange traded derivatives. This result is not surprising as there is no organized Derivatives Exchange in most African countries. Besides, OTC contracts are tailor made, highly flexible and will be considered most suitable for hedging activities by many firms. This is even true in advanced economies where there are derivatives exchanges. Most firms still prefer to use the OTC derivatives because of its flexibility and customization. Most firms use OTC derivatives to hedge their exchange rate and interest rate exposure because of the flexibility of OTC instruments. The inflexibility of Exchange Traded derivatives limits their usage among firms [32]. Firms use more of OTC derivatives because of the flexibility of OTC contracts. This is true in the US [37], UK [28], New Zealand [35] and even in emerging market economies like Peru [33].

\subsection{Managing Exposures with Derivatives}

Most African Firms indicate that they are mostly affected by exchange rate movements, followed by interest rate movement, then commodity price movement and Equity price movement. On the extent to which the use of derivative instruments has helped to effectively manage the risk associated with the firm exposure to exchange rate, 18 reported that it extremely help, 13 reported that it do help, 20 reported moderate help, 46 reported not so much while 18 reported that it does not help. In all overwhelming majority of 97 out of the 102 respondents (95.10\%) confirm that the use of derivatives has been helpful in managing their firms interest rate exposures.

Regarding interest rate exposure, again an overwhelming majority of 95 out of 102 (93.14\%) confirm that the use of derivatives has been helpful in managing their interest rate exposure. The response on the interest rate revealed that 16 reported that it extremely help, 26 that it helps, 42 that it moderately helps, 11 not so much and 7 do not improve.

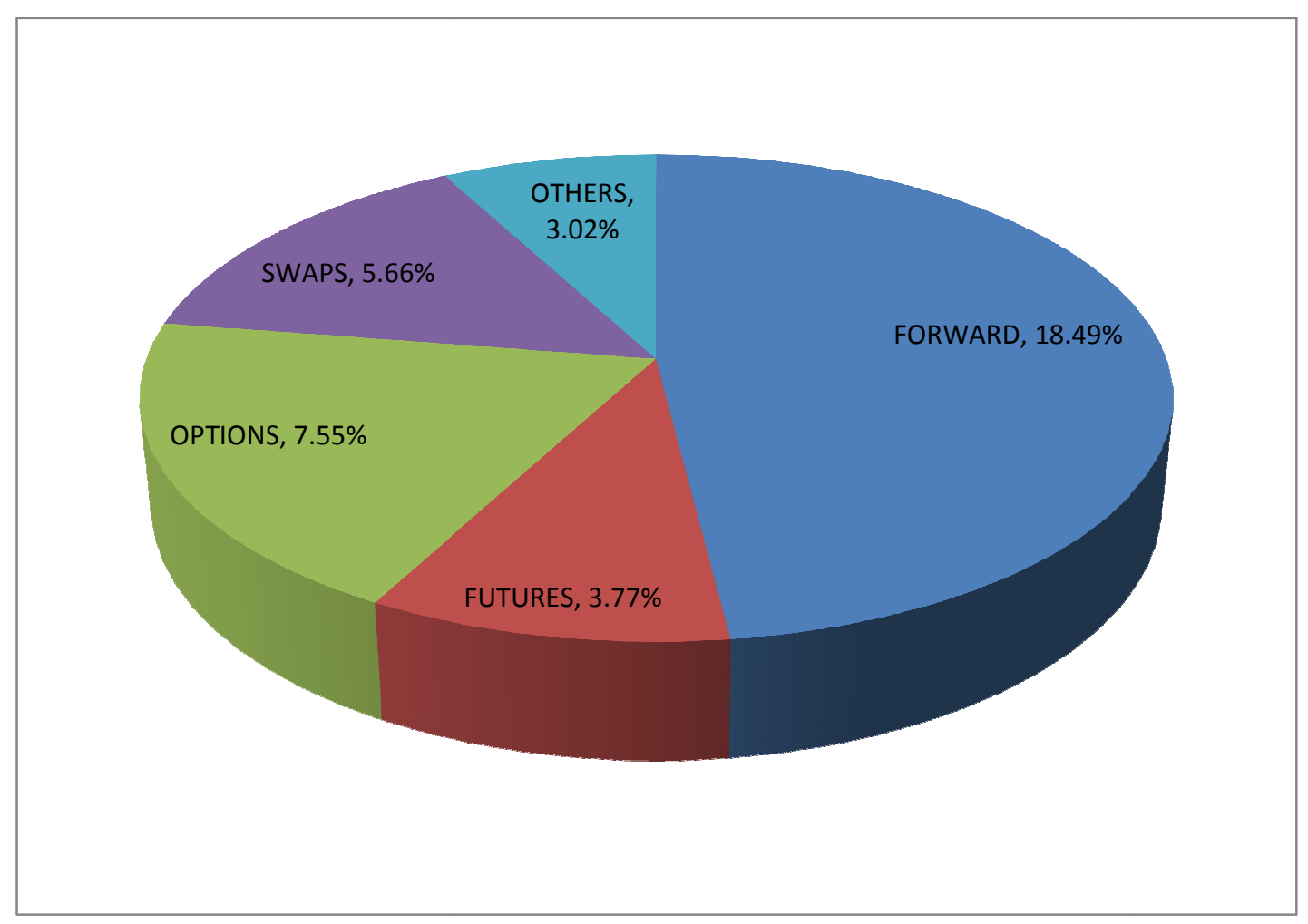

Fig. 4. Types of derivatives in use 
In managing commodity price exposures, 96 out of $102(94.1 \%)$ confirms that it has been helpful. 13 out of the 102 respondents reveal that derivatives usage extremely help commodity price, 55 that it do help, 12 that it moderately help, 16 not so much while 6 reported do not help. For equity price, 94 respondents $(92.16 \%)$ confirm that it has been helpful in managing their risk exposure. The responses on equity price showed that 7 out of the 102 reported that it extremely help equity price, 42 that it do help, 16 that it moderately help, 29 not so much and 8 do not help. In all the four risk exposures examined in the study, overwhelming majority confirm that the use of derivatives has been helpful to their firms in managing these risk exposures (Please see Fig. 5).

\subsection{Logistics Regression Result}

This analysis explains the impact of Corporate Governance on derivatives usage. In order to establish the corporate governance measure with the greatest impact on derivative usage in firms covered in the study, a logistic regression was used in the analysis. The identified dependent variable was "Derivative Usage" while the other 5 factors (Possession of Documented Policy, the
Board Size, Number of executive directors, number of non - executive directors and number of independent directors) were the independent variables. The output of the SPSS recorded the resulting values for each of the 265 observations in the survey (Please see Table 1a in Appendix 1).

The statistics - 2 log likelihood reduces with each iteration; thus making the model a better one. The model summary on Table $1 \mathrm{~b}$ (Appendix 1) gives that the model accounts for between $55.7 \%$ and $75.9 \%$ of the variance in derivative usage. Table 1c (Appendix 1) summarizing the result of our prediction gave that the model correctly predicts the outcome for $86.6 \%$. Therefore we have correctly predicted $77.9 \%$ of derivative usage by the corporate governance measures. Table 1d (Appendix 1) gave some of the most useful information. The first column gives the co-efficients for each predictor variable in the model. The negative coefficients for board size indicate that derivative usage decrease with the rise in the number of directors. This findings tallies with an earlier study where it was found that the size of the board (BS) was found not to be significantly related to the quantity of corporate derivatives use [20].

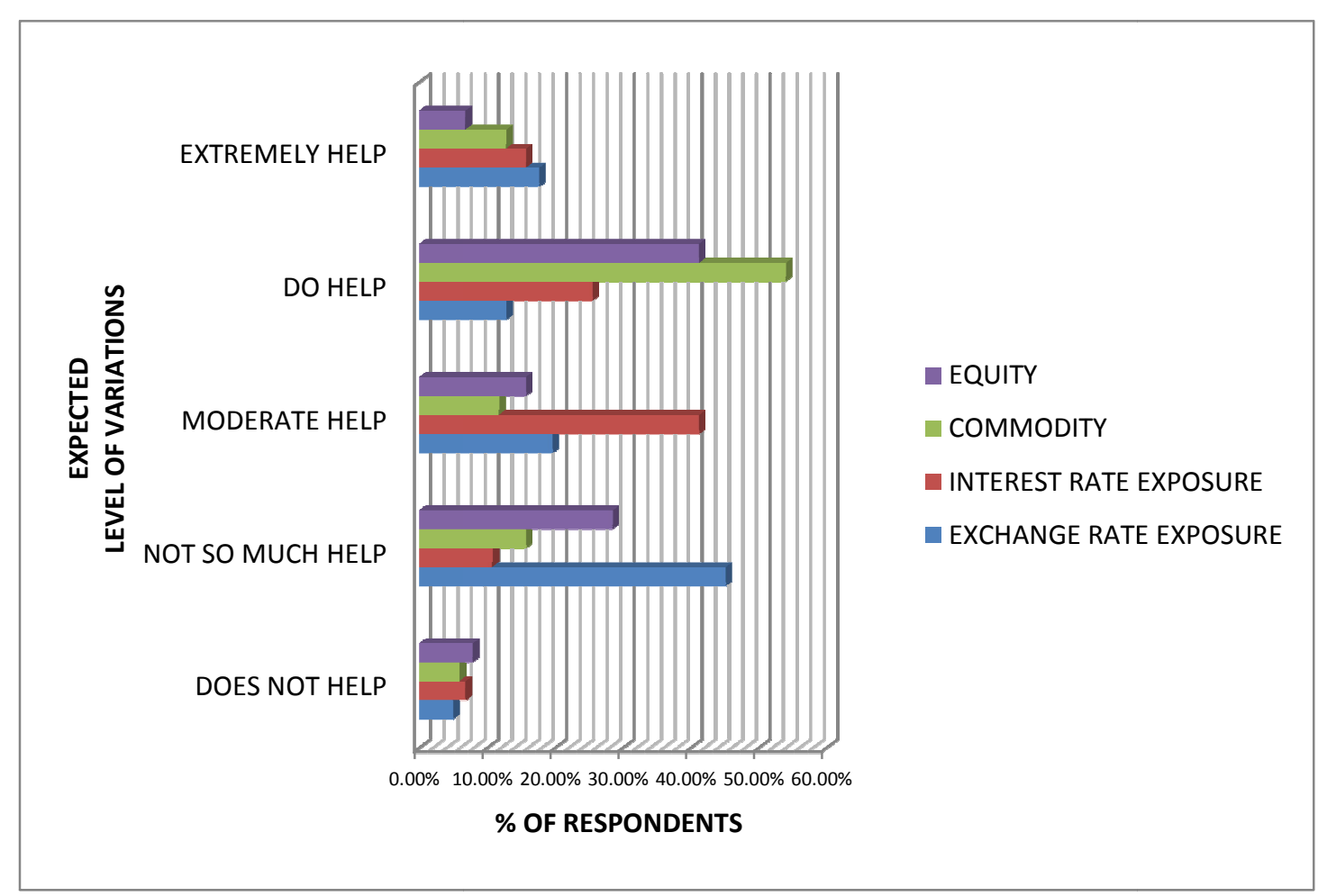

Fig. 5. Efficiency of managing exposures through derivatives 
The Wald Statistics and the associated sig values indicate that only number of executive directors is significant. Conclusively after a step wise procedure which ensured the best selection of variables, the result showed that the most significant relationship is between derivative use and board composition (especially the number of executive directors). This finding may not be surprising to many scholars. Experience in the corporate world suggests that a board dominated by executive directors will have higher appetite for risk, which may result to engaging in more risky projects that may require the need to use derivatives to hedge such exposures. A board dominated by non-executive directors may moderate risk taking, encourage less risky projects that could lead to minimizing the need to use derivatives. This suggests that the present Board structure prevalent in most African firms and other markets based on the agency theory principles of corporate governance; where there are more non- executive directors than executive directors may be contributing to the low level of usage of derivatives. Most corporate governance codes do encourage a board structure with more non-executive directors. It is believed that such structure will be more effective in monitoring board's use of derivatives. To encourage increased use of derivatives, there may be need to revisit corporate governance codes of practice across African countries. This findings contradicts the finding in a study "Board Composition \& Corporate use of Interest rate Derivatives" by [20] in which it was found that there exist a significant and positive relation between the quantity of derivatives usage by firms and the proportion of outside directors on the Board. In a survey of the understanding and monitoring of derivatives in a small sample of quoted firms, the survey was designed to find out if the non-executive directors have the where withal to oversee a firm's derivatives policy. Two-thirds of the non- directors confessed inadequate knowledge of derivatives; three quarters favoured the use of derivatives in appropriate circumstances [38]. This lack of knowledge of derivatives among non-executive directors may be responsible for low use of derivatives by firms dominated by non-executive directors as they cannot give what they don't have. Just like [22] argues that Independent Directors have not demonstrated any special skill to manage risk. In all, the presence of good corporate governance will help firms gain maximally from their corporate derivatives usage. As observed by [15], foreign currency hedging premium is statistically significant and economically large for firms that have strong internal and external corporate governance. [39] also show that firms with strong corporate governance use derivatives in beneficiary ways to the firm. One of the most important aspects of derivatives control is Board- level approval (Grant\& Marshall [34]).

\section{CONCLUSION I SUMMARY OF FINDINGS}

Considering the nature of derivatives, its two edged sword nature that can be defensive and at the same time harmful, its electricity nature that can transform and at the same time can deform if misused [5], as well as the possibility of misuse, there is need to establish a sound system of corporate governance in firms and economies that use or plan to introduce derivatives across their markets, as in the case of Africa. Good corporate governance will help moderate the risk of derivatives misuse in Africa financial markets. From our study the board composition mostly influence derivatives usage among African firms while board size has an inverse relationship with derivatives usage. These both show that the corporate governance practice, board structure, composition and size do affect firms' decision to use derivatives. African firms that use derivatives must strive to support their derivative usage with strong corporate governance to avoid cases of derivatives misuse that could hurt the firm severely. We can summarize the findings which have been discussed above as follows:

1. Derivatives usage by African non-financial firms is very low at $38.5 \%$ and the three major factors attributed to the low usage are lack of knowledge about derivatives, absence of organized derivatives market and absence of derivatives experts.

2. Large African firms tend to use derivatives much more than small firms. The rate of Derivatives usage among large firms is $54 \%$ while $19 \%$ of small firms use derivatives.

3. Over the Counter Derivatives is much more in use just like in many other studies. The flexibility and customized nature of OTC derivatives may have been responsible for this trend.

4. A large percentage of the firms (67\%) are increasing their derivatives usage suggesting that they may be finding derivatives beneficial and effective in managing their risks, which motivates them to increase its usage 
5. Board Composition is the most significant Corporate Governance measure that affects African firms' use of derivatives. However, derivatives usage decreases with rise in the board size but increase with rise in the number of executive directors.

6. Most African firms that use derivatives have strong corporate governance in place to check and monitor derivatives usage. Most have in place and Audit Committee (AC) and particularly a Risk Management Committee (RMC) that oversees risk management and derivatives usage within the firm.

\section{COMPETING INTERESTS}

Authors have declared that no competing interests exist.

\section{REFERENCES}

1. Taylor F. Mastering derivatives Market, A step by step guide to the products, application and risks. 4th edition, Pearson Education Ltd, prentice Itd/Financial Times; 2011.

2. Osuoha J. Financial engineering, corporate governance and Nigeria economic development. Journal of Financial Risk Management. 2013;2(4):61-66. Scientific Research Publishers, (SCIRP) United States of America.

3. $\mathrm{Hu} \mathrm{H}$. Financial innovation and corporate governance. NACD Directorship. 2011;5052.

4. Osuoha Jl. Financial futures and options. Emmaesth Publishing, Lagos, Nigeria; 2008.

5. Osuoha J. Transforming Nigeria economy through the use of derivatives. Advances in Applied Economics and Finance. 2013; 4(1):668-677. World Science Publishers, United States of America.

6. Hull J. Introduction to futures and options market. Prentice Hall, India; 2006.

7. Al-shboul M, Alison S. The effects of the use of corporate derivatives on the foreign exchange rate exposure. Journal of Accounting-Business \& Management; 2009.

8. Sheleifer A, Vishny RW. A Survey of corporate governance. Journal of Finance. 1997;52(2):73.

9. Cadbury. Cadbury Report on Corporate Governance, UK; 2003.

10. OECD. OECD publications on Corporate Governance; 2004.
11. Gobel PJ. (2003) in W. Sun Corporate Governance and the Directors, Leeds Metropolitan University, UK; 2010.

12. Al-shboul M, Alison $\mathrm{S}$. The effects of the use of corporate derivatives on the Shiu and Moles (2010). A publication on Derivatives; 2009.

13. Osuoha J. Derivatives valuation and analysis, Emmaesth Publishing, Lagos, Nigeria; 2014.

14. Buckley, Van De net, Derivatives knowledge among Board Members; 2003.

15. Allayannis $\mathrm{G}$, et al. Corporate governance and the hedging premium around the World. Working Papers Indiana University Foreign Exchange Rate Exposure. Journal of Accounting-Business \& Management; 2004.

16. Osuoha J. Corporate governance and derivatives usage- preliminary analysis of selected quoted firms in Nigeria. Presentation to Stockbrokers, Chartered Institute of Stockbrokers Lectures; 2015.

17. Osuoha Jl. Management, governance and ethics' ICAN Lecture series, Pass Associates Ltd, Lagos, Nigeria; 2014.

18. FCIC. Causes of global financial crises. Financial Crises Inquiry Commission, United States; 2011.

19. Fama EF, Jensen MC. Seperation of ownership and control. Journal of Law and Economics. 1983;26:301-325.

20. Borokhovich K, et al. Board composition and corporate use of interest rate derivatives. The Journal of Financial Research. 2004;32(2):199-216. Blackwell Publishing Ltd.

21. Giffth SJ. Governing systemic risk: Towards a governance structure for derivatives clearing houses. Emory Law Journal. 2011;61:1153.

22. Achleitner A, et al. Do corporate governance motives drive hedge fund and private equity fund activities? European Financial Management. 2010;16(5):805828. Blackwell Publishing Ltd.

23. Breeden (2004) in Pantos TD. The OTC global derivatives Markets: An expositional analysis, Journal of Derivatives \& Hedge Funds. 2008;13(4).

24. Smith CW, Stulz RM. The determinants of firms hedging policies. Journal of Financial and Quantitative Analysis. 1985;20:391405.

25. May D. Do managerial motives influence firm risk reduction strategies. Journal of Finance. 1995;40:1291-1308. 
26. Tufano $P$. Who manages risk? An empirical analysis of risk management practices in the gold mining industry. Journal of Finance. 1996;51:1097-1137.

27. Bodnar GM, Marston RC, Hagt GS. 1994 Survey of financial risk management by US Non-financial firms. Financial Management; 1995.

28. Berkman $\mathrm{H}$, Badbury $\mathrm{M}$. Empirical evidence on the corporate use of derivatives. Financial Management. 1996; 25:5-13.

29. Yanigida M, Inui K. Survey of derivatives usage among non-financial Japanese firms. NLI Research; 1995.

30. Nguyen H, Faff F. On the determination of derivatives usage by Australian companies. Australian Journal of Management. 2002;27:1-24.

31. Rivas-Chavez AE. Three Essays on the use of Financial Derivatives by Latin American Banks in Brazil, Chile and Mexico, Austin TX: The University of Texas - Pan American; 2003.

32. Martin MA, Rogers W, Evoausgun J. Derivatives Usage by non-financial firms in emerging market: The Peruvian case. Journal of Economies, Finance \& Administrative Science; 2009.
33. Tijani $O$, Mathias $O$. Derivatives and financial risk management in Nigeria: Evidence from non-financial firms. African Journal of Scientific Research. 2013;11(1).

34. Grant K, Marshall Large UK companies and derivatives. European Financial Management. 1997; 3:192-208.

35. Prevost, Rose, Miller. Derivatives usage and financial risk management in large and small economies: A comparative analysis. Journal of Business Finance and Accounting. 2000;27:733-759.

36. Bodnar GM, Gebhardt G. Derivatives usage in risk management by US and German non-financial firms: A comparative survey. Journal of International Financial Management. 1999;25(winter):113-133.

37. Bodnar GM, Hagt GS, Master RC. Wharter Survey of financial Risk management by US. Non-financial firms. Financial Management. 1998;27:70-91.

38. Buckley, Van De net Derivatives knowledge among Board Members; 2003.

39. Allayanis $G$, Lel $U$, Miller D. The use of foreign currency derivatives, corporate governance and firm value around the World. Journal of International Economies; 2012. 


\section{APPENDIX 1}

Table 1. Logistic regression

Table 1A. Case processing summary

\begin{tabular}{|c|c|c|c|}
\hline Unweighted cases $^{a}$ & & $\mathbf{N}$ & Percent \\
\hline \multirow[t]{3}{*}{ Selected cases } & Included in analysis & 65 & 24.5 \\
\hline & Missing cases & 200 & 75.5 \\
\hline & Total & 265 & 100.0 \\
\hline \multicolumn{2}{|l|}{ Unselected cases } & 0 & .0 \\
\hline \multicolumn{2}{|l|}{ Total } & 265 & 100.0 \\
\hline \multicolumn{4}{|c|}{$\begin{array}{l}\text { a. If weight is in effect, see classification table for the total number of cases. } b \text {. The category variable item 19a is } \\
\text { constant for the selected cases. Since a constant term was specified, the variable will be removed from the } \\
\text { analysis }\end{array}$} \\
\hline \multicolumn{4}{|c|}{ Case processing summary } \\
\hline \multicolumn{2}{|l|}{ Unweighted cases $^{\mathrm{a}}$} & $\mathbf{N}$ & Percent \\
\hline \multirow[t]{3}{*}{ Selected cases } & Included in analysis & 228 & 86.0 \\
\hline & Missing cases & 37 & 14.0 \\
\hline & Total & 265 & 100.0 \\
\hline Unselected cases & & 0 & .0 \\
\hline Total & & 265 & 100.0 \\
\hline
\end{tabular}

a) If weight is in effect, see classification table for the total number of cases

Table 1B. Model summary

\begin{tabular}{llll}
\hline Step & $\mathbf{- 2}$ Log likelihood & Cox \& Snell R square & Nagelkerke R square \\
\hline 1 & $116.506^{\mathrm{a}}$ & .557 & .759 \\
\hline
\end{tabular}

a) Estimation terminated at iteration number 20 because maximum iterations has been reached. Final solution cannot be found

Table 1C. Classification Table ${ }^{a}$

\begin{tabular}{llllll}
\hline & Observed & & \multicolumn{2}{l}{ Predicted } & \\
\cline { 3 - 5 } & & & item1a & & Percentage correct \\
\cline { 3 - 5 } & & yes & no & \\
\hline Step 1 & item1a & Yes & 67 & 19 & 77.9 \\
& & No & 7 & 135 & 95.1 \\
& \multirow{2}{*}{ Overall percentage } & & & 88.6 \\
\hline
\end{tabular}

a. The cut value is .500 
Table 1D. Variables in the equation

\begin{tabular}{llllllll}
\hline & & B & S.E. & Wald & df & Sig. & Exp(B) \\
\hline Step 1 $^{\mathrm{a}}$ & POLICY(1) & -23.884 & 4391.047 & .000 & 1 & .996 & .000 \\
& BS a & & & .084 & 3 & .994 & \\
BS(1) & -22.344 & 22910.782 & .000 & 1 & .999 & .000 \\
BS(2) & -22.057 & 4391.047 & .000 & 1 & .996 & .000 \\
BS(3) & -21.822 & 4391.047 & .000 & 1 & .996 & .000 \\
BCa & -.260 & .121 & 4.589 & 1 & .032 & .771 \\
BCb & -.070 & .093 & .557 & 1 & .455 & .933 \\
BCc & -.265 & .191 & 1.929 & 1 & .165 & .767 \\
Constant & 26.693 & 4391.047 & .000 & 1 & .995 & $3.914 \mathrm{E} 11$ \\
\hline \multicolumn{6}{l}{ a. Variable(s) entered on step 1: item15a, item17a, item17ba, item17bb, item17bc. }
\end{tabular}

a. Variable(s) entered on step 1: item15a, item17a, item17ba, item17bb, item17bc.

(c) 2015 Osuoha et al.; This is an Open Access article distributed under the terms of the Creative Commons Attribution License (http://creativecommons.org/licenses/by/4.0), which permits unrestricted use, distribution, and reproduction in any medium, provided the original work is properly cited.

Peer-review history:

The peer review history for this paper can be accessed here: http://www. sciencedomain.org/review-history.php?iid=1061\&id=20\&aid=9215 